\title{
WASTE ELIMINATION TO INCREASE PRODUCTIVITY IN SMALL MEDIUM INDUSTRIES KEMBANGAN WEST JAKARTA
}

\author{
Zulfa Fitri IKATRINASARI ${ }^{*}$ and Kosasih KOSASIH ${ }^{2}$ \\ ${ }^{1}$ Industrial Engineering Departement, Universitas Mercu Buana \\ ${ }^{2}$ Management Departement, Universitas Mercu Buana \\ "zulfa.fitri@mercubuana.ac.id
}

\begin{abstract}
Productivity can increasing through eliminating waste, with a low cost, the company can reduce selling prices which will further increase market opportunities. Waste identification itself is a tool used to achieve lean industries, also known as lean manufacturing. This requires knowledge and skills in identifying and eliminating waste for management and employees in the Kembangan sub-district. Green manufacturing is a method in manufacturing to minimize/eliminate waste and pollution through product and process design with the main objective being sustainable. This service activity aims to provide knowledge, understanding and skill of the eliminate waste in small industry. Seven wastes are transportation, inventory, motion, waiting, over processing, over production and delay. The results of the evaluation showed that all participants (100\%) agreed with questions 1) Does the webinar material provide insight? 2) Does the webinar material increase knowledge? 3) Does the webinar material increase understanding in identifying waste in business activities, 4) Does the webinar material help overcome the problem of waste in business activities? 5) Do webinars need to be held on an ongoing basis? While in the implementation time, 28 people agree that the implementation time needs to be extended and 21 people think that the implementation time does not need to be extended.
\end{abstract}

Keywords: Lean Manufacturing, Green Manufacturing, Kembangan-West Jakarta.

\section{BACKGROUND}

The home industry or small and medium industry (SMIs) has an important role that is directly, able to boost regional income, become a driver of economic activity that is able to absorb labor, and reduce poverty. SMIs as the backbone of the economy, SMIs are expected to be able to realize economic independence, so as to be able to develop regions and villages. Based on data from the Ministry of Industry, it states that in 2016, SMIs in Indonesia grew to reach 165,983 units, an increase of 4.5 percent compared to 2015 and have absorbed a workforce of 350,000 people (Julianto, 2016). In addition, SMEs are also able to absorb the most labor compared to other sectors. Absorption of labor in the non-oil sector (food, crafts, clothing, etc.) at the beginning of 2016 reached 97.22 percent. Considering the important role of SMIs, therefore, the government strives to always try to improve the competitiveness of SMEs business through coaching and revitalization programs.

Many factors affect the stages of the development of SMIs in Indonesia. Some things that were reviewed to be the cause of the weak development of SMIs according to Tambuan (2002) cited by Wiratech (2015) are the limitations of human resources. Human resources is a serious obstacle for SMEs, especially in the aspects of management, production techniques or product innovation. Lack of expertise in production and management techniques will have an impact on the low efficiency, productivity, and cost effectiveness in product / service business activities.

There is one concept that is known to help improve efficiency, productivity, and cost effectiveness in product / service business activities. This term is called seven waste reduction. Seven waste is one of the concepts of production control to maximize output and minimize costs (cost effectiveness) by identifying activities / activities that are not necessary in a series of production / service processes. Seven wastes originated from Japan, which was later developed into a concept by Toyota Chief Engineer Taiichi Ohno as the core of the Toyota Production System, also known as Lean Manufacturing. To eliminate this waste, it is important that you understand what waste is and where it occurs in the production of products / services. The types of waste that have been summarized by Jackson (2013) are as follows: Overproduction, Over processing (Processes that are not appropriate / excessive), Defects (many defective products), Waiting (a lot of waiting time), Transport (ineffective transportation), Inventory (excess inventory), Over Motion (unnecessary movement).

This time the community service will focus on the Small and Medium Industries in West Jakarta. SMIs in West Jakarta is dominated by industries engaged in food (restaurant), trade, and hotels as many as 4,318 business units (BPS Statistical Data, 2017) where this sector accounts for more than $22 \%$ of total GDP in Million rupiahs. On average, this industry is run by small capital entrepreneurs who employ 5-19 workers and have limited human resources and technology. As has been explained by Wiratech (2015) that there is no skilled and knowledgeable workforce in production techniques as one of the potential weaknesses that causes SMIs to lag.

The community service team wants to contribute by providing coaching and counseling to improve the ability of human resources at SMIs, especially in the aspects of productivity and cost effectiveness so that it can realizing SMIs that are able to make savings where savings are expected to help the activities of the production / service process can run better, the minimum costs incurred, the maximum profit generated so that the development opportunities in other aspects of the SMIs can be maximized. 


\section{METHOD}

Providing understanding to SMIs about the importance of identifying and reducing waste in production activities to develop and advance SMIs. Implementation is carried out for one day by WEBINAR online zoom meeting. The duration of the activity consists of 3-4 hours. The audience owner of SMIs that located in North Kembangan, Kembangan sub-district, West Jakarta.

After the implementation of the development activities, the service team will evaluate whether the SMIs have been able to identify what their waste is included in the 7 types of waste and where it came from? Or is SMIs able to eliminate the waste? Then the implementation team will make a return visit to the partner location to see the effectiveness of the assistance activities.

\section{RESULT AND DISCUSSION}

Community service activities through the PPM Series webinar with the theme Industry and Environmental Conservation with the title Waste Elimination to Increase Productivity in Small Medium Industries Kembangan West Jakarta were held online on January 27, 2021. This activity was attended by the Head of the Village and the people of North Kembangan administrators and members of the North Kembangan PKK, administrators and members of the North Kembangan Youth Organization and the North Kembangan Community who have Small and Medium Industries.

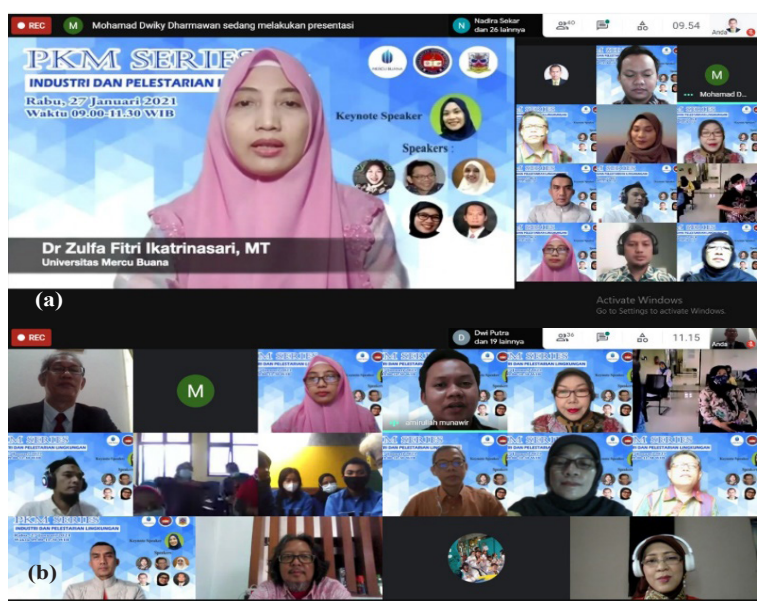

Figure 1. Online Community Service Activity

This community service activity is a collaboration with the Sultan Idris Education University of Malaysia, in this case represented by Prof. Dr. Assoc. Che Zalina Zulkifli who gave material about community service activities in Malaysia in the field of environmental management.

This activity was opened by the Head of North Kembangan, the Dean of the Faculty of Engineering and the Chair of the Mercu Bana University Community Service Center. The Head of North Kembangan Urban Village appreciated this activity because the community got benefits in increasing knowledge and skills in reducing waste in the UMKM process.
This activity went well and smoothly. This can be seen from the timeliness of the implementation and the enthusiasm of the participants in question and answer and discussion. The question asked by the participants about lean manufacturing materials was how it applies to home industries. The concept of lean manufacturing is a concept that is easy to implement, but requires consistency in improving / reducing waste on an ongoing basis.

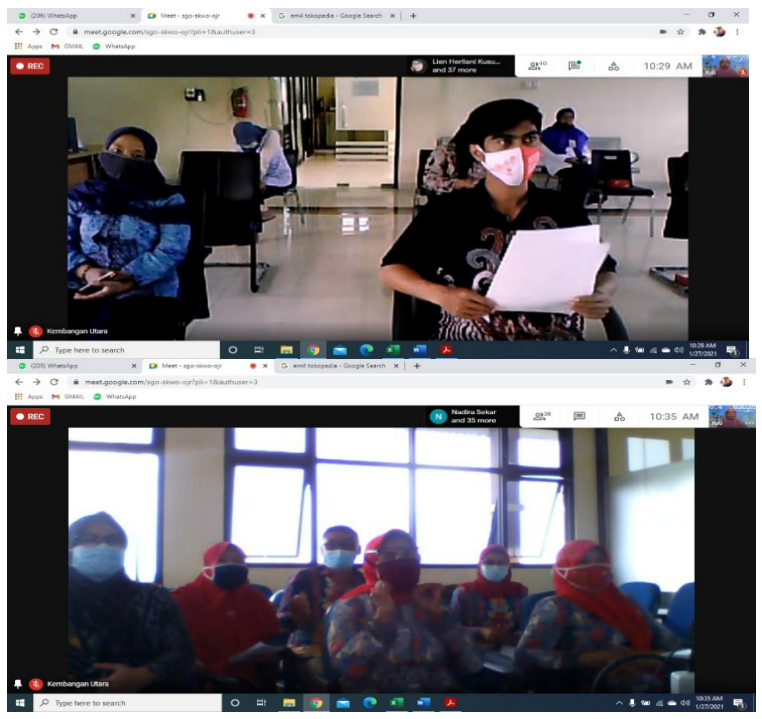

Figure 2. Offline Community Service Activity

Lean manufacturing is one of the concepts that can increase efficiency through eliminating waste. Waste consists of: Transportation, Inventory, Motion, Waiting, Over Processing, Over Production, Defect (TIMWOOD).

Transportation (T). Poor plant design can cause waste in transportation. It can also trigger other wastes such as waiting or motion and impact overhead costs such as higher fuel and energy costs and higher overhead labor in the form of lift drivers as well as adding wear and tear on equipment. It may also result from poorly designed processes or processes that have not been changed or updated as often as required. Value stream mapping and partial or full changes in factory layout can reduce transportation waste. This is a full documentation of all aspects of the production flow and not just the mapping of a specific production process. This results in changes to reduce or eliminate transportation waste. Common types of Transportation Waste: Poor layouts - large distance between operations, Long material handling systems, Large Batch sizes, Multiple storage facilities, Poorly design production systems.

Inventory (I), Inventory is considered a form of waste because of the related holding costs. This is true of raw materials, WIP and finished goods. Over purchasing or poor forecasting and planning can lead to inventory waste. It may also signal a broken or poorly designed process link between manufacturing and purchasing/scheduling. Lean Manufacturing does not just focus on the factory but also requires process optimization and communication between support functions. Purchasing, scheduling and 
forecasting can have a version of standardized work in the form of defined minimums and maximums and order points that are mapped to the process flow and takt time. Purchasing raw materials only when needed and reducing WIP and eliminating or narrowing the definition of "safety stock" will reduce this type of waste. Common causes of Inventory Waste include: Overproduction of goods, Delays in production or 'waste of waiting', Inventory defects, Excessive transportation.

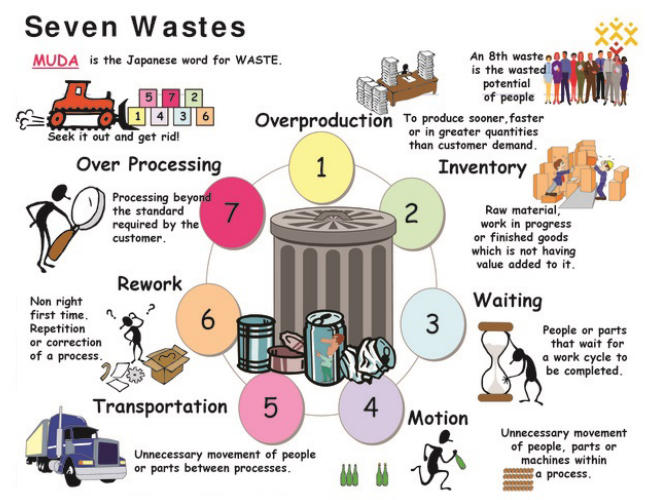

Figure 3. Seven Wastes of Lean

Motion (M). Motion costs money. This not only includes raw materials but also people and equipment. It may also include excess physical motion such as reaching, lifting and bending. All unnecessary motion results in nonvalue-added time and increases cost. Again, referencing core Lean Manufacturing methodology, process mapping should include facility layout and optimized workplace design that includes analysis of the distance of motion within the space as well as the location of parts, supplies and tools within the space as well. As an effective process map is developed, proper utilization of the space can be captured with well designed and documented standard work. Common Motion Waste examples include: Poor workstation layout, Poor production planning, Poor process design, Shared equipment and machines, Siloed operations, Lack of production standards.

Waiting (W). Waiting can include people, material equipment (prior runs not finished) or idle equipment (mechanical downtime or excess changeover time). All waiting costs a company has in terms of direct labor dollars and additional overhead costs can be incurred in terms of overtime, expediting costs and parts. Waiting may also trigger additional waste in the form of defects if the waiting triggers a flurry of activity to "catch up" that results in standard work not being followed or shortcuts being taken. In many ways, waiting is the opposite of overproduction. However, it can be mitigated or eliminated with many of the same remedies. Waiting is often the result of poor process design and can be addressed through proper measurement of takt time and the creation of standard work. Common causes of Waiting include: Unplanned downtime or Idle equipment, Long or delayed set-up times, Poor process communication, Lack of process control, Producing to a forecast, Idle equipment.
Over Processing (O). Over processing is a sign of a poorly designed process. This could be related to management or administrative issues such as lack of communication, duplication of data, overlapping areas of authority and human error. It may also be the result of equipment design, inadequate job station tooling or facility layout. Process mapping is a lean waste elimination tool that helps define an optimized workflow that can eliminate over processing. As a key method within lean production, process mapping is not limited to the performance of production tasks. It also includes reporting, signoff and document control. Examples of Over Processing include: Poor communication, Not understanding, your customers' needs, Human error, Slow approval process or excessive reporting.

Overproduction (O). When components are produced before they are required by the next downstream process, overproduction occurs. This has several negative effects. It creates a "caterpillar" effect in the production flow and results in the creation of excess WIP This leads to staging and therefore labor required to move the WIP additional times. And it can hide defects that could have been caught with less scrap if processes were balanced to allow detection earlier as earlier use of the WIP components would have revealed the defect in time to correct the issue. Lean manufacturing systems utilize several tools to combat overproduction. Takt time is used to balance production rates between cells or departments. Measured and process-mapped jobs result in reduced setup time allowing efficient small batch flow. And in many industries, "pull" systems such as Kanban can be used to help control or eliminate WIP. Common causes of Overproduction include: Unreliable process, Unstable production schedules, Inaccurate forecast and demand information, Customer needs are not clear, Poor automation, Long or delayed set-up times.

Defect (D). Defects impact time, money, resources and customer satisfaction. Examples of Defects within a manufacturing environment include lack of proper documentation or standards, large variances in inventory, poor design and related design documentation changes and an overall lack of proper quality control throughout the process workflow. Formalized document control and design change documentation, thorough and documented quality methods in all production phases and checklists that have been audited to ensure proper adherence to the BOM are effective ways to control defect waste. And standardized work at each production cell or point in the production line will help reduce this type of waste as well. Specific Defect causes include: Poor quality control at the production level, Poor machine repair, Lack of proper documentation, Lack of process standards, Not understanding your customers' needs, Inaccurate inventory levels.

The evaluation of this community service activity was carried out by giving an evaluation questionnaire to 
the 49 participants after the activity ended. The questions on the questionnaire are: 1) Does the webinar material provide insight? 2) Does the webinar material increase knowledge?, 3) Does the webinar material increase understanding in identifying waste in business activities, 4) Does the webinar material help overcome the problem of waste in business activities?, 5) Do webinars need to be held on an ongoing basis?, 6) Does the time for the webinar need to be extended?

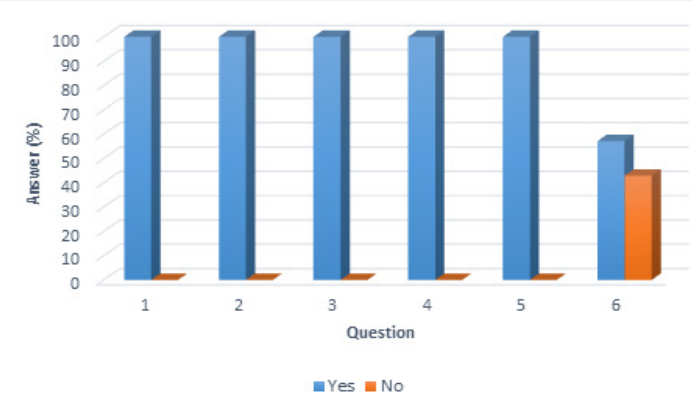

Figure 4. Result of the evaluation community service activity

The results of the evaluation showed that all participants (100\%) agreed with questions number 1 to question number 5 . While in question no. 6 regarding the implementation time, 28 people agree that the implementation time needs to be extended and 21 people think that the implementation time does not need to be extended.

\section{CONCLUSIONS}

The service was carried out well and received a positive response from the participants. Lean manufacturing training activities can increase participants' understanding to improve work efficiency. This activity was greatly appreciated by the participants, because it was hoped that with this activity could increase efficiency. Most participants hoped for continued activities because there was not enough time available. The activity organizing team was asked to guide further implementation of the lean concept.

\section{REFERENCES}

Data Statistik BPS. https://jakbarkota.bps.go.id/ linkTabelStatis/view/id/25

Jackson, B. 2013. Seven Waste. Workshop Presentation Premera Blue Cross Association. Diakses dari: http://www.results.wa.gov/sites/default/files/ The $\% 207 \% 20$ Wastes.pdf

Julianto, P.A. 2016. Pemerintah Pacu Pertumbuhan Industri Kecil Menengah. Diakses pada http://ekonomi. kompas.com/read/2016/12/30/190450026/ pemerintah.pacu.pertumbuhan.industri.kecil. menengah.

Lean manufacturing.org. 2015. Diakses dari http:// leanmanufacturingtools.org/wp-content/ uploads/2016/11/seven-wastes.pdf

Wiratech.com. 2015. Keunggulan dan Kelemahan Usaha Kecil \& Menengah. Diakses pada https://wiratech. co.id/keunggulan-dan-kelemahan-usaha-kecil-danmenengah/. 